\title{
LUMBAR CANAL STENOSIS
}

By Col A. S. Chahal, V.S.M., M.S., F.R.A.C.S., Lt Col Y. J. Mundkur, M.S., H. K. Sancheti, M.S., D. Ortho, R. Arora, M.B.B.S. and P. RAstogi, M.B.B.S.

Department of Orthopaedics, Armed Forces Medical College, Pune-I, India

Abstract. Lumbar canal stenosis has been well recognised as a cause of low backache. A study was undertaken to find out the incidence of lumbar canal stenosis in Indian adults from I July I978 to 30 June I98I. The diagnosis was based on clinical, radiological and myelographic findings. The majority of adults in the fourth decade were found to be suffering from degenerative arthritis of the apophyseal joints with thickened ligamentum flavum. Congenital stenosis cases were few. Decompression of the stenosed canal by laminectomy of the stenosed segments and excision of thickened ligamentum flavum, or any osseous element in the posterolateral compartment, gave lasting relief from backache and intermittent claudication. Incidence of pure relative stenosis is higher than pure absolute stenosis amongst Indian adults.

Key words: Lumbar spinal stenosis; absolute; relative; mixed.

\section{Introduction}

LOW BACKACHE is a common condition occuring in many adults. The increased incidence of this disorder has been attributed to industrialisation and change in the life style of modern living. Today's man is far more dependent on machines than his ancestors. He exerts himself physically less but suffers from backache more often. During the last two to three decades extensive research has focused attention on the syndrome of lumbar canal stenosis.

\section{History}

Lumbar canal stenosis has been classified into congenital or developmental and acquired. Verbiest (1975) in his article, 'Pathomorphological aspects of developmental stenosis', mentions that Portal in I803 was the first to describe narrowing of the spinal canal as the cause of compression of its contents. Sarpyener (1945) described congenital stenosis of vertebral canal in children and young adolescents often associated with spina bifida. Verbiest (1954) reported seven cases of osseous stenosis of the lumbar spinal canal in adults in whom stenosis was attributed to reduction of the midsagittal diameter and thickening of laminae. In that study he described absolute stenosis in which narrowing produced signs and symptoms of cauda equina compression and relative stenosis in which minor spondylotic spurs, soft protrusions or hypertrophic ligaments compressed the cauda equina nerve roots.

Blau et al. (I96I) reported intermittant claudication of the cauda equina as a syndrome resulting from central prolapse of an intervertebral disc. Paine (1976) also discussed the clinical features of spinal stenosis in great 
detail. Jones et al. (I968) reviewed the narrow lumbar canal and correlated the radiological features with the clinical signs. Epstein et al. (1977) described the radiological features of spinal canal stenosis and classified them into segmental and localised stenosis. The last two lumbar segments have localised stenosis more often than those above this level. According to Epstein (1977), spinal stenosis is suspected on plain films and confirmed by myelography. Ehni (1969) stressed the significance of spondylosis in the small lumbar canal. Neurogenic claudication has been attributed to ischaemia of nerve roots (Wilson et al., I97I).

From India, Suba Rao (1970) and Dinaker (1976) have reported on the radiological features of lumbar canal stenosis. During 1972 and 1973 we came across some cases clinically and radiologically diagnosed as prolapse of the I.V. Disc who did not show evidence of prolapse at operation. However, they were relieved of backache and sciatica by decompressive laminectomy. We attributed the cause of the pain to narrowing of the lumbar canal or thickening of the ligamentum flavum, a common finding in these cases. In I978 we undertook a study of lumbar canal stenosis in adults in India as an AFMRC Research Project.

\section{Observations and Results}

This paper is based on the study carried out from July 1978 to June I98I and during this period a total of 350 cases of low backache were treated in Orthopaedic OPD at Command Hospital (SC) Pune-I. There were only 46 cases of lumbar canal stenosis in this group. Of the 32 operated upon the clinical and radiological findings have been analysed to correlate with operative findings.

Age

The highest incidence was in the age group 3 I to 40 , I I out of 32 accounting for 36.7 per cent. Incidence diminished over 60 years and none was seen below the age of 20 (Table I).

\section{TABLE I}

Age incidence

\begin{tabular}{lcc}
\hline Age & No of patients & Percentage \\
\hline 2 I to 30 & 4 & I2.5 \\
3 I to 40 & I I & $34 \cdot 3$ \\
4 I to 50 & 8 & $25 \cdot 0$ \\
5 I to 60 & 6 & I $8 \cdot 7$ \\
6 I to 70 & 3 & $9 \cdot 4$ \\
Total & 32 & \\
\hline
\end{tabular}

Sex

There were ten females and 22 males. As a service hospital more serving and retired males reported for treatment. 
Trauma

A history of trauma was present in seven cases.

Symptoms and their duration

The duration of symptoms ranged from 3 months to 20 years, the average duration being 4 years and 3 months. The majority were suffering for more than I year (Table II).

TABLE II

Duration of symptoms

\begin{tabular}{lcc}
\hline Duration in months & No of patients & Percentage \\
\hline Less than 6 months & 4 & I $2 \cdot 5$ \\
7 to I2 months & 5 & I $5 \cdot 6$ \\
I3 to 24 months & I I & $34 \cdot 3$ \\
More than 24 months & I2 & $37 \cdot 5$ \\
Total & 32 & \\
\hline
\end{tabular}

Low backache

Low backache was present in all 32 cases.

\section{Sciatica}

Sciatica was present in 25 , being unilateral in II and bilateral in I4. Claudication on walking was the presenting feature in 13 cases. The distance varied from 50 metres to 500 metres (Table III).

TABLE III

Symptoms

\begin{tabular}{lcc}
\hline Nature of symptoms & No of patients & Percentage \\
\hline Low backache & 32 & I00 \\
Sciatic pain & 25 & $78 \cdot$ I \\
a) Unilateral & I 3 & $40 \cdot 6$ \\
b) Bilateral & I 2 & $37 \cdot 5$ \\
Claudication & I 4 & $43 \cdot 8$ \\
Sphincter disturbances & 2 & $6 \cdot 2$ \\
\hline
\end{tabular}

\section{Sphincter disturbances}

Two patients (males) reported inability to empty the bladder without straining. They had a residual urine 150 to $200 \mathrm{ml}$. 


\section{Clinical signs}

Tenderness over the spine was present in 18 i.e. 60 per cent. Muscle spasm with restriction of movements was present in 19 and scoliosis was seen in six. Obliteration of lumbar lordosis was present in $2 \mathrm{I}$ cases.

Straight leg raising test was restricted to less than $50^{\circ}$.

\section{Neurological deficit}

Twelve patients had evidence of diminished sensation to fine touch over the legs and feet. Only five had weakness of dorsiflexors of toes and ankles. The ankle jerk was sluggish or absent in I I while the knee jerk was weak or absent in three.

\section{Radiological signs}

Osteoarthritic change in apophyseal joints was a frequent finding. Fifteen showed evidence of spondylosis and five showed posterior vertebral osteophytes confirmed as bony ridges at surgery (Table IV).

TABLE IV

Radiological signs

\begin{tabular}{lcc}
\hline Radiological findings & No of patients & Percentage \\
\hline $\begin{array}{l}\text { Pure development } \\
\text { narrowing }\end{array}$ & 3 & $9 \cdot 4$ \\
Osteoarthritis & & \\
$\quad$ Apophyseal joints & I9 & $59 \cdot 3$ \\
Spondylosis & I3 & 40.6 \\
Posterior & & \\
$\quad$ vertebral osteophytes & 5 & 15.6 \\
Spondylolisthesis & 2 & $6 \cdot 2$ \\
\hline
\end{tabular}

\section{Measurement of spinal canal}

Interpedicular distances were normal in most of the cases except two. The midsagittal diameter was found to reduce gradually from $\mathrm{L}_{\mathrm{I}}$ to $\mathrm{L}_{5}$, being narrowest at L5 level (Table V). Pure absolute stenosis in three cases, relative stenosis in 23 and mixed stenosis was present in six cases. L5 showed evidence of stenosis in 26 cases, $\mathrm{L}_{4}$ in $22, \mathrm{~L}_{3}$ in five cases and $\mathrm{L}_{2}$ in two cases. Relative stenosis was more common in our series and the midsagittal diameter was more significant than the Jones Index in determining spinal canal stenosis.

\section{Myelography}

Filling defects were found at levels where the midsagittal diameter was less than I $2 \mathrm{~mm}$. Maximum blocks were seen at $\mathrm{L}_{4}$, $\mathrm{L}_{5}$ level i.e. $88 \cdot 8$ per cent. Some had two or three level blocks (Table VI). 
TABLE V

Absolute and relative stenosis at all levels

\begin{tabular}{|c|c|c|c|c|c|c|}
\hline \multirow[t]{2}{*}{ Level } & \multicolumn{2}{|c|}{$\begin{array}{l}\text { Absolute stenosis } \\
\text { MSD less than } \\
\text { I0 mm }\end{array}$} & \multicolumn{2}{|c|}{$\begin{array}{l}\text { Relative stenosis } \\
\text { MSD Io to I } 2 \mathrm{~mm}\end{array}$} & \multicolumn{2}{|c|}{$\begin{array}{l}\text { No stenosis } \\
\text { MSD more than } \\
\text { I } 2 \mathrm{~mm}\end{array}$} \\
\hline & No & Percentage & No & Percentage & No & Percentage \\
\hline $\mathrm{L}_{\mathrm{I}}$ & - & - & I & $3 \cdot I$ & 29 & $96 \cdot 7$ \\
\hline $\mathrm{L}_{2}$ & - & - & 2 & $6 \cdot 2$ & 28 & $93 \cdot 3$ \\
\hline $\mathrm{L}_{3}$ & I & $3 \cdot I$ & 6 & I 6.7 & 25 & $83 \cdot 3$ \\
\hline $\mathrm{L}_{4}$ * & 5 & 15.6 & I 8 & $60 \cdot 0$ & 7 & $23 \cdot 3$ \\
\hline $\mathrm{L}_{5}$ & 7 & $20 \cdot 0$ & 20 & $66 \cdot 7$ & 4 & 13.3 \\
\hline
\end{tabular}

^MSD-Mid-sagittal diameter

TABLE VI

Levels of myelographic defects/blocks

in 29 patients

\begin{tabular}{ccc}
\hline $\begin{array}{c}\text { Levels of } \\
\text { defects/blocks }\end{array}$ & Number & Percentage \\
\hline Li-L2 & I & $3 \cdot 4$ \\
L2-L3 & 7 & $23 \cdot 8$ \\
L $_{3}-L_{4}$ & I & $40 \cdot 8$ \\
L4-L5 & 25 & $85 \cdot$ I \\
L5-SI & I 7 & $57 \cdot 8$ \\
\hline
\end{tabular}

\section{Treatment}

Decompression laminectomy at a single level was done in I3, at two levels in 14 and at three levels in five. Disc excision was carried out in 12 in addition to laminectomy. In four osteophytes were excised but no attempt was made to excise bony ridges.

\section{Operative findings}

Thickened laminae were present in eight. Thickened ligamentum flavum between $\mathrm{L}_{4} \mathrm{~L}_{5}$ and $\mathrm{L}_{5} \mathrm{~S}_{\mathrm{I}}$ was seen in $\mathrm{I}_{2}$ cases varying from $5 \mathrm{~mm}$ to IO $\mathrm{mm}$ in thickness. Less than $4 \mathrm{~mm}$ was considered normal. Posterior vertebral osteophytes were present in six cases. Spondylolisthesis (2nd degree), was present in two. Disc protrusion was present in 12 and of these four had disc protrusion at $\mathrm{L}_{4} \mathrm{~L}_{5}$ Level and eight had at $\mathrm{L}_{5} \mathrm{~S}_{\mathrm{I}}$ level.

Results were good in 24, fair in five and poor in three. All of them had had conservative treatment for months prior to surgery. Only three were not satisfied after operation as their low backache persisted. Twentytwo cases with good results were free from backache or sciatica on follow-up from six to 30 months. Five cases with a fair result suffered from backache on exertion or in cold weather. They all had extensive osteoarthritis. 


\section{Discussion and Conclusion}

In this study the duration of symptoms prior to surgery was 4 years and 3 months (range 6 months to 20 years), on average. Getty (I980) reported a delay of 5-8 years (range 6 months to 30 years) and Paine (I976) reported a delay of seven years. The delay was most often amongst retired personnel and females than in serving soldiers. Degenerative arthritis (being a slowly progressive disorder), appears to be the cause of delay as most patients continue conservative treatment for years before submitting to operative measures.

Our clinical findings are similar to Getty, including absent ankle jerks, diminished sensation and motor weakness in legs, all highly suggestive of cauda equina compression due to lumbar stenosis. Epstein (I977) also reported similar findings.

We have classified our patients according to Verbiest (I975) into pure absolute stenosis where midsagittal diameters were less than Io $\mathrm{mm}$. Verbiest (1975, I977) reported a high percentage of pure absolute stenosis attributed to developmental causes but in our series there were only three examples of pure absolute stenosis. However, there were 23 cases of relative stenosis with associated prolapse I.V. Disc in 12 and osteophytes or bony ridges in six. Our findings suggest that in Indian adults in the fourth decade degenerative arthritis or thickening of ligamentum flavum produces cauda equina compression in a relative stenotic spine, with midsagittal diameter less than $2 \mathrm{~mm}$ at $\mathrm{L}_{4}$, L5 vertebrae. Yong et al. (I976) described the significance of the ligamentum flavum in compression of the cauda equina.

Results were good in 73.3 per cent as compared to 55 per cent in Getty's series. Paine (I976) reported that about 80 per cent returned to their usual occupation. Twelve of our patients with good results are now serving soldiers who have resumed full military duties. They were free from backache and sciatica during follow-up. Five patients with fair result still suffer from occasional bachache, they exhibit extreme osteoarthritic changes and one has had a second exploration. Failure in three cases was due to inadequate lateral decompression as recommended by Schatzker and Pennal (I968), or to progressive degenerative changes in the spine which will be confirmed on further follow-up. Verbiest (1977) has cautioned about the dangers of too generous a decompression and reported slipping of vertebrae following extensive laminectomies from L2 to $L_{5}$. We had no slipping in our series as only five had a three level laminectomy whereas I4 had a two level laminectomy and I3 one level. Results of adequate but conservative laminectomies have been good in this short follow-up of 6 to 30 months.

A diagnosis of lumbar canal stenosis must be entertained in low backache cases past the age of 30 years. Relative absolute stenosis at $\mathrm{L}_{5} \mathrm{~L}_{4}$ level is more common in Indian adults. Degenerative lesions, prolapsed I.V. disc and hypertrophied ligamentum flavum were the additional stenosing elements in our cases. Developmental stenosis or pure absolute stenosis was seen only three times. Adequate decompression laminectomy with clearing of thickened ligament from interlaminar region and sides of pedicles with excision of the disc (if prolapsed), gave good 
results. Relief from sciatica and claudication was considered a good index of successful surgery.

\section{SUMMARY}

Thirty-two cases of lumbar canal stenosis were diagnosed from a group of 350 low backache sufferers.

Over 70 per cent had symptoms for more than a year. Sciatic pain was present in 78 per cent and intermittent claudication in 43.8 per cent. Three had pure absolute stenosis, 23 had pure relative stenosis and six were mixed. Diagnosis was made on radiological measurements and confirmed by myelography and surgery. Osteoarthritis of apophyseal joints and spondylosis was a common finding in pure relative stenosis. A thickened ligamentum flavum was present in 25 per cent. Decompression laminectomy of one lamina was carried out in 13, of two laminae in I5 and of three laminae in four. Results were good in 24, fair in five and poor in three cases on 6 months to 30 months follow up. This study has revealed that lumbar canal stenosis is present amongst adults in India. However, the stenosis is acquired rather than developmental and is more often pure, relative or of a mixed type.

\section{RÉSUMÉ}

32 cas de sténose du canal lombaire ont été diagnostiqués dans un groupe de 350 personnes souffrant de douleurs lombaires basses.

Plus de $70 \%$ de ces patients se plaignaient de douleurs depuis plus d'un an. Dans $78 \%$ de cas on notait la présence de douleurs de type sciatique et dans $43.8 \%$ de cas on relevait une claudication intermittente. On notait une sténose totale chez 3 personnes, une sténose relative chez 23 personnes et une atteinte mixte chez 6 personnes. Le diagnostic a été posé d'après des données radiologiques et confirmé par myélographie et chirurgie. Lorsqu'il s'agissait de sténoses relatives on pouvait invariablement constater une ostéoarthrite des articulations des apophyses ainsi qu'un spondylolysthésis. Dans $25 \%$ de cas on notait un ligament jaune défectueus. Une laminectomie décompressive d'une lame a été pratiquée dans I 3 cas, de deux lames dans I 5 cas et de 3 lames dans 4 cas. Après 6 à 30 mois de suivi, les résultats notés étaient bons dans 24 cas, moyens dans 5 cas et médiocres dans 3 cas. Cette étude a permis de révéler la présence de sténoses du canal lombaire parmi la population adulte en Inde. Cependant ces sténoses sont acquises plutôt que d'installation progressive et sont le plus souvent de type relatif ou mixte.

\section{ZUSAMMENFASSUNG}

Unter 350 Patienten mit tiefsitzenden Rückenbeschwerden hatten 32 eine Einengung des lumbalen Wirbelkanals.

Bei mehr als $70 \%$ bestanden die Beschwerden länger als ein Jahr. Ischiasbeschwerden klagten $78 \%$, intermittierendes Hinken gaben $48 \%$ an. In 3 Fällen lag eine absolute, in 23 Fällen eine relative und in 6 Fällen eine gemischte Stenose vor. Die Diagnose wurde röntgenologisch gestellt, bestätigt durch Myelographie und Operation. Bei den relativen Stenosen lagen gewöhnlich eine Arthritis der Wirbelgelenke und eine Spondylose vor. In 25 Fällen fand sich eine Verdichtung des gelben Bandes. Bei der dekomprimierenden Laminektomie wurden 13 mal I Wirbelbogen, I 5 mal 2 Wirbelbögen und 4 mal 3 Wirbelbögen entfernt.

Über einen Nachuntersuchungszeitraum von 6-30 Monaten war das Ergebnis $24 \mathrm{mal}$ gut, $5 \mathrm{mal}$ ausreichend, $3 \mathrm{mal}$ unzureichend. Die Untersuchung bestätigt das Vorkommen lumbaler Wirbelkanalstenosen in Indien bei Erwachsenen. Meistens handelt es sich um eine erworbene und nicht um eine Entwicklungsstörung. Die relativen und die Mischformen überwiegen. 
BlaU, J. N. \& Logue, V. (I96I). Intermittant claudication of the cauda equina. Lancet, I, IO8I-I086.

Dinaker, I., Haridas \& Deshpande, R. P. (1976). Lumbar Canal Stenosis. I. f. Rad., 30, 378-379.

EhNi, G. (I969). Significance of the small lumbar canal. Cauda equina compression syndrome due to spondylosis. F. Neurosurg., 31, 490-494.

Epstein, B. S., Epstein, J. A. \& Jones, M. D. (I977). Lumbar spinal stenosis. Rad. Clin. North America. XV, 2, 227-239.

Getty, G. J. M. (1980). Lumbar spinal stenosis. F.B.F.S., 62 B, 482-485.

Jones, R. A. C. \& Thomson, J. L. G. (I968). 'The narrow lumbar canal'. f.B.F.S., $50 \mathrm{~B}, 595-605$.

PaINE, K. W. E. (1976). Clinical features of lumbar spinal stenosis. Clin. Orthopaedics, II 5, 96-100.

RaO, K. S., RaO, D. B., Gouridevi, M. \& Reddy, D. B. (1970). Lumbar canal stenosis. Ind. F. Rad., 24, 198-204.

SARPYENER, M. A. (I945). Congenital stricture of the spinal canal. F.B.F.S., 27, 70-79.

Schatzker, J., Pennal, G. F. (I968). Spinal stenosis a cause of cauda equina compression. F.B.F.S., 506, 606-618.

VERBIEST, H. (I954). Radicular syndrome from developmental narrowing of the lumbar vertebral canal. F.B.F.S., $36 \mathrm{~B}, 230-237$.

Verbiest, H. (1975). Pathomorphologic aspects of developmental lumbar stenosis. Orthopaedics Clin., 6, I I 7-195.

VERBIEST, H. (I977). Results of surgical treatment of idiopathic developmental stenosis of lumbar vertebral canal. F.B.F.S., 59 B, $18 \mathrm{I}-188$.

Wilson, C. B., EhNi, G. \& GrollmuS, J. (I97I). Neurogenic intermittant claudication. Clin. Neurosurg., 18, 62-66.

Yong-Hing, K., Reilly, J. \& Kirkaldy-Willis, W. H. (I976). The ligamentum flavum. Spine, I, 226-234. 